medRxiv preprint doi: https://doi.org/10.1101/2020.10.24.20218925; this version posted October 27, 2020. The copyright holder for this preprint (which was not certified by peer review) is the author/funder, who has granted medRxiv a license to display the preprint in

All rights reserved. No reuse allowed without permission.

\title{
Associations between Alzheimer's disease polygenic risk scores and hippocampal subfield volumes in 17,161 UK Biobank participants
}

Heidi Foo $^{\mathrm{a}}$, Anbupalam Thalamuthu ${ }^{\mathrm{a}}$, Jiyang Jiang ${ }^{\mathrm{a}}$, Forrest Koch ${ }^{\mathrm{a}}$, Karen A. Mather ${ }^{\mathrm{a}, \mathrm{b}}$, Wei Wen $^{\mathrm{a}}$, Perminder S. Sachdev ${ }^{\mathrm{a}, \mathrm{c}}$

a Centre for Healthy Brain Aging, CHeBA, School of Psychiatry, University of New South Wales Medicine, Kensington, New South Wales 2052, Sydney, Australia

b Neuroscience Research Australia, Randwick, New South Wales 2031, Sydney, Australia c Neuropsychiatric Institute, Euroa Centre, Prince of Wales Hospital, Randwick, New South Wales 2031, Sydney, Australia

Corresponding author:

Heidi Foo

Centre for Healthy Brain Aging, CHeBA, School of Psychiatry, UNSW Medicine, Kensington 2052, Sydney, Australia

Tel: +61 293823763

Fax: +61293823774

e-mail: heidi.foo@student.unsw.edu.au 
medRxiv preprint doi: https://doi.org/10.1101/2020.10.24.20218925; this version posted October 27,2020 . The copyright holder for this preprint (which was not certified by peer review) is the author/funder, who has granted medRxiv a license to display the preprint in

All rights reserved. No reuse allowed without permission.

\begin{abstract}
Hippocampal volume is an important biomarker of Alzheimer's disease (AD), and genetic risk of $\mathrm{AD}$ is associated with hippocampal atrophy. However, the hippocampus is not a uniform structure and has a number of subfields, the associations of which with age, sex, and polygenic risk score for $\mathrm{AD}\left(\mathrm{PRS}_{\mathrm{AD}}\right)$ have been inadequately investigated. We examined these associations in 17,161 cognitively normal UK Biobank participants (44-80 years). Age was negatively associated with all the hippocampal subfield volumes and females had smaller volumes than men. Higher PRS $\mathrm{AD}_{\mathrm{A}}$ was associated with lower volumes in the bilateral whole hippocampus, hippocampal-amygdalatransition-area (HATA), and hippocampal tail; right subiculum; left cornu ammonis (CA)1, CA4, molecular layer, and granule cell layer of dentate gyrus (CG-DG), with associations being greater on the left side. Older individuals (median age 63 years, $n=8984$ ) showed greater subfield vulnerability to high $\mathrm{PRS}_{\mathrm{AD}}$ compared to the younger group $(\mathrm{n}=8177)$, but the effect did not differ by sex. The pattern of subfield involvement in relation to the $\mathrm{PRS}_{\mathrm{AD}}$ in community dwelling healthy individuals sheds additional light on the pathogenesis of AD.
\end{abstract}

Keywords: Hippocampal subfields, Alzheimer's disease, Polygenic risk score, Ageing 
medRxiv preprint doi: https://doi.org/10.1101/2020.10.24.20218925; this version posted October $27,2020$. The copyright holder for this preprint (which was not certified by peer review) is the author/funder, who has granted medRxiv a license to display the preprint in All rights reserved. No reuse allowed without permission.

\section{Introduction}

Hippocampal atrophy is one of the most validated and widely used biomarkers of Alzheimer's disease (AD) (de Flores et al., 2015). However, the hippocampus is not a homogenous structure and differential vulnerability of the hippocampal subfields to neurodegeneration has been reported to affect different cognitive functions (Mueller et al., 2010). Decline in volumes of hippocampal subfields have been associated with age and sex. Studies in healthy adults have shown significant age effects in CA1-2 (Daugherty et al., 2016; Mueller et al., 2007; Pini et al., 2016; Shing et al., 2011; Wisse et al., 2014), dentate gyrus (DG) (Daugherty et al., 2016; Wisse et al., 2014), and CA4 volumes (Wisse et al., 2014). Evidence has been presented for an anterior-posterior gradient in hippocampal volume reduction (Malykhin et al., 2017) with age, which implies that the hippocampal subregions are not uniformly affected along the hippocampal axis. Significant decreases in cornu ammonis (CA) 1 and subiculum volumes and shape have been observed in participants with mild cognitive impairment (MCI) and AD (de Flores et al., 2015; Pini et al., 2016). Moreover, sex differences in hippocampal subfield volumes have also been observed - males had larger parasubiculum, fimbria, hippocampal fissure, and presubiculum - whereas females had larger volumes for the hippocampal tail (van Eijk et al., 2020). It has also been shown that total hippocampal volume loss in females was more pronounced than males (Nobis et al., 2019). However, to date, there is a lack of studies examining sex differences of hippocampal subfield volumes in greater detail. Therefore, it is important to further study the impact of normal ageing and sex on hippocampal subregions and to determine whether AD genetic risk selectively and differentially impacts distinct subfields.

While one heritability study using twins by Elman et al. (2019) showed little genetic impact on subfields after accounting for total hippocampus volume, a recent genome-wide association study (GWAS) on hippocampal subfield volumes derived from FreeSurfer reported that genetic determinants varied across different subregions (van der Meer et al., 2018). The 
medRxiv preprint doi: https://doi.org/10.1101/2020.10.24.20218925; this version posted October $27,2020$. The copyright holder for this preprint (which was not certified by peer review) is the author/funder, who has granted medRxiv a license to display the preprint in All rights reserved. No reuse allowed without permission.

authors found that the volumes of all hippocampal subfields were heritable in individuals with a mean age of approximately $47.8($ standard deviation $=17.3)$ years $\left(\mathrm{h}^{2}\right.$ range: $\left.0.14-0.27\right)$. They identified genome-wide significant single nucleotide polymorphisms (SNPs) associated with the whole hippocampus, presubiculum, subiculum, CA1, dentate gyrus, molecular layer, and hippocampal tail. In addition, in their follow-up analyses on age-stratified subsamples, they also investigated the genetic overlap with $\mathrm{AD}$ and showed that three of the significant SNPs were associated with hippocampal subfield volumes in the older age group. This study showed that the differences in cytoarchitecture of the hippocampal subfields are partially driven by genetic variation and that $\mathrm{AD}$-related genes may influence the hippocampal volume predominantly later in life.

Previous studies have identified several common risk variants for AD beyond the wellestablished apolipoprotein E epsilon 4 allele (APOE- $\varepsilon 4)$ (Li et al., 2018; Xiao et al., 2017). However, these risk alleles have shown small effects on disease risk (Desikan et al., 2015; Lambert et al., 2013). Other studies have used the $\mathrm{AD}$ polygenic risk score ( $\left.\mathrm{PRS}_{\mathrm{AD}}\right)$ to examine the cumulative genetic risk for AD (Dezhina et al., 2018; Li et al., 2018), which has shown improvements in predicting cognitive decline beyond the $A P O E$ locus (Escott-Price et al., 2015).

As hippocampal subfield volumes are differentially affected in the early stages of AD (Zhao et al., 2019), it is possible that this is driven by the genetic risk for AD. Moreover, the $\mathrm{PRS}_{\mathrm{AD}}$ may have a differential effect on the subfield volumes in a cohort of non-demented individuals. To date, there has not been any study to investigate the relationship between $\mathrm{PRS}_{\mathrm{AD}}$ and hippocampal subregions, which could help understand the relationship between AD genetic risk factors, ageing, and the pathobiology of AD.

The overall aim of this this study was to investigate hippocampal volumes subfields in greater detail in a large cohort using the UK Biobank data of $n=17,161$ participants. The study had three main objectives: (1) to investigate the relationships between age, sex, and hippocampal 
medRxiv preprint doi: https://doi.org/10.1101/2020.10.24.20218925; this version posted October $27,2020$. The copyright holder for this preprint (which was not certified by peer review) is the author/funder, who has granted medRxiv a license to display the preprint in

All rights reserved. No reuse allowed without permission.

subfield volumes; (2) to examine the effects of $\mathrm{PRS}_{\mathrm{AD}}$ constructed using genome-wide significant AD risk variants (Lambert et al., 2013) on hippocampal subfield volumes; (3) to study the interaction of age and sex with the effects of PRS $\mathrm{AD}$. We hypothesised that age and sex would be associated with hippocampal subfield volumes. We also hypothesised that there would be varying effects of PRS $\mathrm{AD}_{\mathrm{D}}$ across the different hippocampal subfield volumes, with higher genetic risk of AD being differentially associated with lower hippocampal subfield volumes. We also hypothesised that $\mathrm{PRS}_{\mathrm{AD}}$ would be modulated by age and sex on hippocampal subfield volumes.

\section{Materials and methods}

\subsection{Participants}

The UK Biobank, which is a large prospective cohort study, included participants from the United Kingdom aged between 40 and 80 years old (Sudlow et al., 2015). Participants provided full informed consent to participate in the UK Biobank and ethics approval was given by the National Health Service National Research Ethics Service (Ref 11/NW/0382).

For this study, cross-sectional data released in January 2019 was used. UK Biobank provided 19,363 participants who had T1-weighted magnetic resonance imaging (MRI) data. Image preprocessing was successful for only 19,275 participants. After quality control filtering and including those with complete brain imaging, genetics, and cognitive data, a final sample of 17,161 participants of European descent was included (see sections 2.2 and 2.3 for more details).

\subsection{Imaging acquisition and preprocessing}

Briefly, the UK Biobank structural T1-weighted MRI scans were acquired on three 3T Siemens Skyra MRI scanners (software platform VD13) at three sites (Reading, Newcastle, and Manchester) using a 32-channel receiving head coil and a 3D MPRAGE protocol $(1.0 \times 1.0 \times 1.0$ mm resolution, matrix $208 \times 256 \times 256$, inversion time $(\mathrm{TI}) /$ repetition time $(\mathrm{TR})=880 / 2,000 \mathrm{~ms}$, 
medRxiv preprint doi: https://doi.org/10.1101/2020.10.24.20218925; this version posted October $27,2020$. The copyright holder for this preprint (which was not certified by peer review) is the author/funder, who has granted medRxiv a license to display the preprint in All rights reserved. No reuse allowed without permission.

in-plane acceleration 2). An extensive overview of the data acquisition protocols and image processing carried out on behalf of the UK Biobank can be found elsewhere (Alfaro-Almagro et al., 2018; Miller et al., 2016).

Using the structural T1-weighted MRI images, cortical reconstruction and volumetric segmentations were performed with FreeSurfer v6.0.0 (https://surfer.nmr.mgh.harvard.edu) in our lab. The technical details have been described previously (Fischl \& Dale, 2000). Briefly, image processing steps included: motion correction, average of multiple volumetric T1-weighted images, removal of non-brain tissues, automated Talairach transformation, intensity normalisation, segmentation of subcortical white and deep grey matter volumetric structures, tessellation of the grey and white matter boundary, automated topological correction, and surface deformation to optimally place the grey/white and grey/cerebrospinal fluid boundaries (Fischl \& Dale, 2000). Hippocampal subfields were segmented using a Bayesian inference approach and novel atlas using ultra-high resolution ( $\sim 0.1 \mathrm{~mm}$ isotropic) ex vivo data from autopsy brains (Iglesias et al., 2015). The left and right hippocampi were further segmented into twelve subregions namely, CA1, CA2-3, CA4, fimbria, granule cell layer of dentate gyrus (GC-DG), hippocampusamygdala-transition-area (HATA), molecular layer, hippocampal fissure, hippocampal tail, parasubiculum, presubiculum, and subiculum. MRI sequences applied in UK Biobank have been designed by imaging experts to optimise the quality of images (Miller et al., 2016). A machine learning-based quality control toolbox was also applied to T1-weighted scans to exclude those with poor acquisition quality (Alfaro-Almagro et al., 2018). To date, there is a lack of standardised quality control method for subcortical regions. Therefore, for quality control, we first examined the principal component (PCA) plots of the sample and omitted any participants who were above 3 standard deviations for the subfields, total hippocampal volumes, and intracranial volume (ICV). 
medRxiv preprint doi: https://doi.org/10.1101/2020.10.24.20218925; this version posted October 27, 2020. The copyright holder for this preprint (which was not certified by peer review) is the author/funder, who has granted medRxiv a license to display the preprint in

All rights reserved. No reuse allowed without permission.

Given that the hippocampal subfields may also not be uniformly affected along the hippocampal axis, we further investigated this using FreeSurfer v7.1.0.

(https://surfer.nmr.mgh.harvard.edu/fswiki/HippocampalSubfieldsAndNucleiOfAmygdala). This segmentation automatically partitions the hippocampus into head, body, and tail. This parcellation may also be useful to address the issues related the reliability of smaller hippocampal subfield volumes using FreeSurfer v6.0.0.

\subsection{Genotyping and Imputation}

DNA was extracted from stored blood samples that had been collected from participants on their visit to a UK Biobank assessment centre (Bycroft et al., 2018). The genetic data were acquired using two closely related custom arrays: Affymetrix UK Biobank Lung Exome Variant Evaluation (UK BiLEVE) Axiom array or Affymetrix UK Biobank Axiom array (Bycroft et al., 2018). Quality control was performed using the UK Biobank pipeline. Imputed data set was made available where the UK Biobank interim release was imputed to a reference set combining the UK10K haplotype and 1000 Genome Phase 3 reference panels. For more details, refer to http://biobank.ctsu.ox.ac.uk/crystal/refer.cgi?id=157020. Ten principal components generated by the UK Biobank were included as covariates in the statistical model to control for population stratification.

\subsection{Polygenic risk score (PRS) derivation}

PRS are calculated as a weighted sum of risk alleles an individual carries for any particular disease or phenotype. The weights are the effect sizes observed in GWAS of the relevant phenotype (Choi, Mak, \& O’Reilly, 2020). For the current study, PRS derivations were based on the summary statistics from a previous AD GWAS (Lambert et al., 2013). Linkage disequilibrium pruning was performed using the clumping option $\left(\mathrm{r}^{2}>0.2\right)$ and a physical distance threshold of 
medRxiv preprint doi: https://doi.org/10.1101/2020.10.24.20218925; this version posted October $27,2020$. The copyright holder for this preprint (which was not certified by peer review) is the author/funder, who has granted medRxiv a license to display the preprint in All rights reserved. No reuse allowed without permission.

$250 \mathrm{~KB}$ using the R package, PRSice2 (Euesden et al., 2015). We selected an a-priori threshold of $\mathrm{p}$-value $=5 \times 10^{-8}$, because a previous study has shown that strongest effect for this threshold in predicting risk associated with age at $\mathrm{AD}$ onset and that the strength of association was weaker with less stringent PRS thresholds (Leonenko et al., 2019).

The resulting PRS thresholds were z-transformed. As the variants around the APOE locus are well-known to be associated with $\mathrm{AD}$, we additionally examined if the effects observed between PRS $_{\mathrm{AD}}$ and hippocampal subfield volumes were purely due to the SNPs in $A P O E$ locus by excluding all the SNPs in this region Chr19:45,116,911-46,318,605 (GRCh37).

\subsection{Statistical analysis}

All statistical analyses were performed using R version 3.5.1 software (The R Foundation, Vienna, Austria). To achieve normality of the skewed hippocampal subfield volumes data, a rank based inverse normal transformation was applied using the R package RNOmni (McCaw, Lane, Saxena, Redline, \& Lin, 2019).

Linear regression models were also estimated to study the effects of $\mathrm{PRS}_{\mathrm{AD}}$, and $\mathrm{PRS} \mathrm{SD}_{\mathrm{AD}}$ without $A P O E$ genotype on hippocampal subfield volumes. False Discovery Rate (FDR) adjusted p-values were obtained by using Benjamini \& Hochberg (1995) procedure as implemented in the $\mathrm{R}$ function p.adjust. Significance level was set at adjusted $\mathrm{p}<0.05$.

In addition, the sample was split into PRS quartiles to investigate differences among the four PRS groups. The fourth quartile (high $\mathrm{PRS}_{\mathrm{AD}}, \mathrm{n}=4293$ ) was used as the reference risk group and compared to each of the other three quartiles with the reference group. We further investigated differential influence of $\mathrm{PRS}_{\mathrm{AD}}$ in relation to age and sex on hippocampal subfield volumes by splitting the cohort into two groups by its median age of 63 years. Those at and below 63 years were referred to as the younger group $(n=8984)$ and those above 63 years as the older group $(\mathrm{n}=8177)$. 
medRxiv preprint doi: https://doi.org/10.1101/2020.10.24.20218925; this version posted October $27,2020$. The copyright holder for this preprint (which was not certified by peer review) is the author/funder, who has granted medRxiv a license to display the preprint in All rights reserved. No reuse allowed without permission.

Age, $\operatorname{age}^{2}$, sex, age $\times$ sex (i.e. age and sex interaction), $\operatorname{age}^{2} \times$ sex (i.e. $\operatorname{age}^{2}$ and sex interaction), ICV, head position in the scanner, and ten genetic principal components were included in all the analyses as covariates. The imaging and genetic covariates were based on previous literature using the UK Biobank (Elliott et al., 2018).

We also examined the age mediation effect of PRS on the hippocampal subfields. The mediation analysis was done using the R package, mediation (Tingley et al., 2014) and the $p$ values were obtained based on 100000 simulations.

\section{Results}

\subsection{Age-sex differences in hippocampal subfield volumes}

As shown in Table 1, of the 17,161 total participants, $9256(53.9 \%)$ were female and the mean (standard deviation) age was 62.39 (7.43) years. Table 1 shows the hippocampal subfield volumes, showing no significant differences between right and left hemispheres.

All hippocampal subfield volumes were negatively associated with age (Supplementary table 1, Supplementary figure 1). Sex was associated with all hippocampal subfield volumes, except for the left hippocampal tail, with women having lower hippocampal volumes than men in all regions (Supplementary table 1, Supplementary figure 1). Age and sex interactions were also negatively associated with all the hippocampal subfield volumes, except left CA2-3, left CA4, left parasubiculum, and right presubiculum (Supplementary table 1). Taken together, age and sex were significantly associated with the hippocampal subfield volumes.

\subsection{Associations between $P R S_{A D}$ and hippocampal subfield volumes}

Table 2 summarises the associations between $\mathrm{PRS}_{\mathrm{AD}}$ and hippocampal subfield volumes. Left and right hippocampal volumes were negatively associated with $\mathrm{PRS}_{\mathrm{AD}}$. In addition, hippocampal subregions, namely bilateral HATA, bilateral hippocampal tail, right subiculum, 
medRxiv preprint doi: https://doi.org/10.1101/2020.10.24.20218925; this version posted October $27,2020$. The copyright holder for this preprint (which was not certified by peer review) is the author/funder, who has granted medRxiv a license to display the preprint in All rights reserved. No reuse allowed without permission.

left CA1, left CA4, left molecular layer, and left CG-DG, were also found to be inversely associated with PRS $\mathrm{AD}$. The results imply that higher genetic load for AD was related to lower hippocampal subfield volumes. Summary statistics of the regression model corresponding to all the subfield volumes are presented in the supplementary table 1 . When we repeated these analyses controlling for total hippocampal volume in addition to other covariates, the following subfields had significant associations (unadjusted p-value $<0.05$ ) namely, right hippocampal fissure, left HATA, left presubiculum, and left fimbria. However, after FDR adjustment, none of these associations was statistically significant (Supplementary Table 2).

In addition, when we investigated the effect of $\mathrm{PRS}_{\mathrm{AD}}$ on hippocampal subfield volumes segmented into head, body, and tail using FreeSurfer v7.1.0, significant results were observed in all the segmented regions including bilateral whole hippocampus (Supplementary Table 3).

Given that this is not informative on which regions were primarily affected, using the segmentation from FreeSurfer v6.0.0 may shed more light onto the differential vulnerability of the hippocampus. Therefore, we only report findings using the FreeSurfer v6.0.0 segmentation from here on.

To determine whether the effect of $\mathrm{PRS}_{\mathrm{AD}}$ on hippocampal subfield volumes was independent of the $A P O E$ genotype, we looked at the effect of $\mathrm{PRS}_{\mathrm{AD}}$ without SNPs in $A P O E$ locus (Supplementary table 4). As most of the SNPs (73\%) used for $\mathrm{PRS}_{\mathrm{AD}}$ were from chromosome 19, the $\mathrm{PRS}_{\mathrm{AD}}$ without the $A P O E$ locus was not associated with the hippocampal subfields.

\subsection{Modulation of $P R S_{\mathrm{AD}}$ on hippocampal subfield volumes by age and sex}

Higher genetic risk for $\mathrm{AD}$, as specified by comparing the fourth quartile versus the first quartile of the $\mathrm{PRS}_{\mathrm{AD}}$, was associated with increased risk for lower volume in the left whole hippocampal, bilateral HATA, left CA1, left molecular layer, left CG-DG, and right hippocampal 
medRxiv preprint doi: https://doi.org/10.1101/2020.10.24.20218925; this version posted October 27, 2020. The copyright holder for this preprint (which was not certified by peer review) is the author/funder, who has granted medRxiv a license to display the preprint in

All rights reserved. No reuse allowed without permission.

tail compared to those with low $\mathrm{PRS}_{\mathrm{AD}}(\mathrm{OR} 1.04-1.06$, adjusted $p<0.05$; Supplementary table $5)$.

In addition, modulation of $\mathrm{PRS}_{\mathrm{AD}}$ by age in the hippocampal subfield volumes was observed. Risk for volume loss between low and high PRS $_{\mathrm{AD}}$ was similar among younger participants ( $\leq 63$ years old) (Supplementary table 6$)$. Older participants were susceptible to lower bilateral HATA, left CA1, and right hippocampal tail volumes in high versus low $\mathrm{PRS}_{\mathrm{AD}}(\mathrm{OR}$ $2.07-2.55$, adjusted $p<0.012$ ) (Supplementary table 7, figure 1).

There were no significant sex differences in the effect of PRS on subfield volumes (Supplementary tables 8-9, Supplementary figure 2). There were also no significant differences in the hippocampal subfield volumes associations with $\mathrm{PRS}_{\mathrm{AD}}$ when we split the group into quartiles for age and sex (Supplementary tables 10-13).

\subsection{Mediation of age on the relationship between $P R S_{A D}$ and hippocampal subfield volumes}

Given that the findings show age differences in the effect of $\mathrm{PRS}_{\mathrm{AD}}$ on hippocampal subfield volumes, we further examined whether age mediated this relationship. The mediation analysis showed that age mediated the relationship between $\mathrm{PRS}_{\mathrm{AD}}$ and hippocampal subfield volumes (Supplementary table 14).

\section{Discussion}

The main findings of this study are: (i) hippocampal subfield volumes are associated with age and sex; (ii) Higher PRS $_{\mathrm{AD}}$ is associated with lower hippocampal subfield volumes in the left and right whole hippocampus, bilateral HATA, bilateral hippocampal tail, right subiculum, left CA1, left CA4, left molecular layer, and left CG-DG, which suggests differential effect of PRS $\mathrm{AD}_{\mathrm{A}}$ on the hippocampal subfield volumes; (iii) Modulation of $\mathrm{PRS}_{\mathrm{AD}}$ by age, but not sex, on hippocampal subfield volumes, with associations seen in older but not younger individuals; and 
medRxiv preprint doi: https://doi.org/10.1101/2020.10.24.20218925; this version posted October $27,2020$. The copyright holder for this preprint (which was not certified by peer review) is the author/funder, who has granted medRxiv a license to display the preprint in All rights reserved. No reuse allowed without permission.

(iv) the associations between $\mathrm{PRS}_{\mathrm{AD}}$ and hippocampal subfield volumes were driven by the SNPs in the $A P O E$ locus.

Hippocampal subfield volumes were associated with age. In line with previous studies, we reported that all the volumes of hippocampal subfields decrease with age in healthy adults (Daugherty et al., 2016; Malykhin et al., 2017; Zheng et al., 2018). However, the age-related changes in hippocampal subfields varied across studies - whereas one showed decline of CA1-2 and CA3-DG (Malykhin et al., 2017), another found no difference in these subfields across the human lifespan (Daugherty et al., 2016). In addition, hippocampal subfield volumes were also associated with sex in our study. One study using the UK Biobank data reported that total hippocampal volume loss was more pronounced in females than males (Nobis et al., 2019), which corroborates our findings, although this study was based on overlapping samples. However, few studies have examined sex differences in hippocampal subfields, and the focus has been on CA1, CA3, or dentate gyrus (Duarte-Guterman et al., 2015; Koss \& Frick, 2017; McEwen, 2010; Scharfman \& MacLusky, 2017). To date, no study has investigated sex differences in hippocampal subfield volumes. Our study is therefore novel in this regard, and we found that females had significantly lower hippocampal volumes than males in most hippocampal subfield volumes, except for the left fimbria, bilateral GC-DG, bilateral CA4, right HATA, and left hippocampal tail, even after controlling for ICV. However, it remains to be elucidated why this might be. More studies are warranted in order to understand this sex effect on hippocampal subfield volumes. Taken together, these results imply that the hippocampus may have differential vulnerabilities to age and sex. Thus, it may be more valuable to study hippocampus subregions rather than as a whole.

Consistent with previous ante- and post-mortem studies, which reported that participants at higher genetic risk of AD had lower CA1 hippocampal volumes compared to age-matched controls (Padurariu et al., 2012; Zhao et al., 2019), we observed that $\mathrm{PRS}_{\mathrm{AD}}$ was negatively 
medRxiv preprint doi: https://doi.org/10.1101/2020.10.24.20218925; this version posted October $27,2020$. The copyright holder for this preprint (which was not certified by peer review) is the author/funder, who has granted medRxiv a license to display the preprint in All rights reserved. No reuse allowed without permission.

associated with left CA1. Moreover, previous studies have also found that hippocampal subfields, particularly the CA1 and/or subiculum (de Flores et al., 2015), have been reported to be a potential indicator of conversion from $\mathrm{MCI}$ to $\mathrm{AD}$, the higher association observed between $\mathrm{PRS}_{\mathrm{AD}}$ and CA1 may identify individuals at risk of AD. In addition, the dentate gyrus, which shows reduced neurogenesis in AD and ageing (Adler et al., 2018; Hollands et al., 2016), was also observed to be associated with $\mathrm{PRS}_{\mathrm{AD}}$. This implies that $\mathrm{AD}$ genetic risk may be able to predict left CA1 and left dentate gyrus atrophy in healthy adults without overt disease. Confirmed by previous studies reporting that subiculum is involved in early phases of $\mathrm{AD}$, we also showed that subiculum is associated with $\mathrm{PRS}_{\mathrm{AD}}$ (Carlesimo et al., 2015; Zhao et al., 2019). However, presubiculum and fimbria, previously reported to be associated with AD (Carlesimo et al., 2015; Zhao et al., 2019), were not observed in this study. It is possible that atrophy in these regions occurs later in the course of the disease and may not be sensitive in identifying participants at risk of developing $\mathrm{AD}$. Our findings also showed that $\mathrm{PRS}_{\mathrm{AD}}$ was associated with bilateral hippocampal tail, bilateral HATA, left CA4, and left molecular layer. While these regions have not been shown to be involved in the trajectory of $\mathrm{AD}$ in previous studies, they show genetic effects in the pathophysiology of AD. This finding needs to be replicated in order to understand why these additional subfields might be affected.

We also observed that the effects of $\mathrm{PRS}_{\mathrm{AD}} \mathrm{p}$-value threshold of $5 \times 10^{-8}$ were mainly driven by the $A P O E$ genotype. The $A P O E$ genotype is one of the most commonly studied variants in ageing due to the high odds (14.9:1) for developing $\mathrm{AD}$ for $\varepsilon 4$ homozygotes (Farrer et al., 1997). Notably, $A P O E-\varepsilon 4$ has been associated with greater thinning of hippocampal CA1 (Kerchner et al., 2014). Another longitudinal study demonstrated that greater atrophy of the left than right hippocampus was most pronounced in $A P O E-\varepsilon 4$ homozygotes compared to heterozygotes over time (Li et al., 2016). As the attributable fraction to AD risk added by all other polymorphisms besides $A P O E$ was the only about $1.0 \%-8.0 \%$ while $A P O E$ accounted for $27.3 \%$ 
medRxiv preprint doi: https://doi.org/10.1101/2020.10.24.20218925; this version posted October $27,2020$. The copyright holder for this preprint (which was not certified by peer review) is the author/funder, who has granted medRxiv a license to display the preprint in All rights reserved. No reuse allowed without permission.

(Lambert et al., 2013), it is therefore likely that the effect of other polymorphisms is small and is not seen when examining multiple hippocampal subfield volumes. Consequently, it seems that the $A P O E$ genotype makes the most salient contribution to this effect.

Our findings also underline that bilateral HATA, left CA1, and right hippocampal tail showed slightly greater vulnerability in the older age group with those with higher $\mathrm{PRS}_{\mathrm{AD}}$ than lower PRS $\mathrm{AD}_{\mathrm{A}}$. While ageing may negatively affect neuronal homeostasis (Boisvert et al., 2018), it has been observed that the presence of $A P O E-\varepsilon 4$ alters normal function of glial cells and may contribute to accelerated ageing and neurodegenerative disease pathogenesis (Fernandez et al., 2019). One study reported that a $\mathrm{PRS}_{\mathrm{AD}}$ calculated predictability for late-onset $\mathrm{AD}$ of $82.5 \%$ (where the APOE SNPs, rs7412 and rs429358, which determine the ApoE isoforms, alone had predictability of $81.8 \%$ ) and $61.0 \%$ of late-onset $\mathrm{AD}$ conversion from mild cognitive impairment (Chaudhury et al., 2019). They further postulated healthy controls with higher PRS may represent those who eventually develop disease if they had lived longer, as the average age at death for controls with higher PRS was significantly reduced than those with lower PRS (Chaudhury et al., 2019). Given that we observed that bilateral HATA, left CA1, and right hippocampal tail were associated with age, sex, and $\mathrm{PRS}_{\mathrm{AD}}$ in our study, it is possible that changes in these regions may be hallmarks of both normal ageing and AD.

Furthermore, we examined the overlap of the SNPs between the hippocampal subfield GWAS (van der Meer et al., 2018) and in our PRS $\mathrm{AD}_{\mathrm{D}}$ analysis. None of the 60 SNPs used in $\mathrm{PRS}_{\mathrm{AD}}$ were found among the 23 unique GWAS hits across all subfield volumes. However, when we looked at the full list of 25 GWAS summary statistics for the subfields, we found a few SNPs, including rs80307900 and rs12459810 on chromosome 19, and rs7982 on chromosome 8 associated with multiple hippocampal subfield volumes at suggestive significance $(\mathrm{p}<0.05)$ (Supplementary tables 15-16). This implies that AD genes may differentially affect the hippocampal subfield volumes. 
medRxiv preprint doi: https://doi.org/10.1101/2020.10.24.20218925; this version posted October $27,2020$. The copyright holder for this preprint (which was not certified by peer review) is the author/funder, who has granted medRxiv a license to display the preprint in All rights reserved. No reuse allowed without permission.

The challenge to understand why several hippocampal subfield volumes were associated with $\mathrm{PRS}_{\mathrm{AD}}$ remains. Our investigation of $\mathrm{PRS}_{\mathrm{AD}}$ in a non-demented ageing cohort from the UK Biobank found hippocampal subfields that are affected by genetic risk for AD (subtle AD pathology). The participants in this study are community dwelling individuals but as literature has shown, AD pathology begins 10-20 years before the first clinical manifestations (Hof et al., 1996; Perl, 2010). Such findings are supported by a previous study by Foley et al. (2017), which showed an effect of $\mathrm{PRS}_{\mathrm{AD}}$ on hippocampal volume that was detected in young adults. These results suggest that $\mathrm{AD}$ genetic risk may be associated with hippocampal subfield volume changes that have been implicated in the early stages of AD pathology decades prior to disease onset. It should be noted that further multiple insults, such as cardiovascular disease and environmental factors, may be required for AD pathology to fully develop. Longitudinal follow-up of the UK Biobank participants will reveal those participants that go on to develop dementia and will allow a more detailed examination of this question.

The strengths of this study include the well characterised large sample size cohort and the uniformed MRI and genetic methods. Limitations should also be considered. The cross-sectional nature of the study prevents the ability to detect subtle changes in the hippocampal subfield volumes over time within individuals and those who go on to develop AD cannot be identified. In addition, the inherent nature of polygenic analysis precludes identifying specific biological mechanisms that contribute to the hippocampal subfield differences (Foley et al., 2017). Further, given that there has not been any consensus in regards to the optimal $p$-value threshold to use for the PRS analysis and the increase of multiple test burden investigating multiple thresholds, future studies might benefit from investigating the optimal p-value threshold to use. Moreover, comparison of results with existing literature is impeded by the variation in the extraction methods used for calculating subfield volumes. For example, some investigators have used FreeSurfer parcellation like in this study, while others use manual segmentation (van der Meer et al., 2018). 
medRxiv preprint doi: https://doi.org/10.1101/2020.10.24.20218925; this version posted October 27, 2020. The copyright holder for this preprint (which was not certified by peer review) is the author/funder, who has granted medRxiv a license to display the preprint in

All rights reserved. No reuse allowed without permission.

In addition, due to the reported lower reliability of using volumes from smaller subfields, such as the fimbria, hippocampal fissure, HATA, and parasubiculum (Quattrini et al., 2020; Worker et al., 2018), the findings should be carefully interpreted. Furthermore, although it has been observed that years of education is associated with hippocampal subfield volumes (Kang et al., 2018), the lack of information on the years of education in the UK Biobank precludes us from including it as a covariate.

\section{Conclusion}

This study shows that the genetics of $\mathrm{AD}$, specifically the $A P O E$ locus, are a contributing factor for the differential hippocampal subfield vulnerabilities seen in non-demented older adults, and the pattern of volume loss seems to be similar to that observed in the early stages of AD. The effect of PRS $\mathrm{AD}_{\mathrm{D}}$ and specific hippocampal subfield volumes may be useful in allowing us to understand the genetic effects on individual subfields. It furthers our knowledge of the association of $\mathrm{AD}$ risk with subfields of the hippocampus, with a focus specific to the subfields that have not received detailed investigation. Such fine-grained analysis of the hippocampus is arguably important in trying to understand which regions are most vulnerable to $\mathrm{AD}$ pathological mechanisms, and potentially add refinement to the notion of the hippocampus as a biomarker of AD.

\section{Funding}

This research did not receive any specific grant from funding agencies in the public, commercial, or not-for-profit sectors.

\section{Acknowledgements}


medRxiv preprint doi: https://doi.org/10.1101/2020.10.24.20218925; this version posted October 27, 2020. The copyright holder for this preprint (which was not certified by peer review) is the author/funder, who has granted medRxiv a license to display the preprint in All rights reserved. No reuse allowed without permission.

Many thanks to the UNSW Scientia PhD Scholarship Program for their support to Foo, H. This research has been conducted using the UK Biobank Resource (Project ID: 37103). 
medRxiv preprint doi: https://doi.org/10.1101/2020.10.24.20218925; this version posted October 27, 2020. The copyright holder for this preprint (which was not certified by peer review) is the author/funder, who has granted medRxiv a license to display the preprint in All rights reserved. No reuse allowed without permission.

\section{References}

Adler, D. H., Wisse, L. E. M., Ittyerah, R., Pluta, J. B., Ding, S. L., Xie, L., . . Yushkevich, P. A. (2018). Characterizing the human hippocampus in aging and Alzheimer's disease using a computational atlas derived from ex vivo MRI and histology. Proc Natl Acad Sci US A, 115(16), 4252-4257. doi:10.1073/pnas.1801093115

Alfaro-Almagro, F., Jenkinson, M., Bangerter, N. K., Andersson, J. L. R., Griffanti, L., Douaud, G., . . . Smith, S. M. (2018). Image processing and Quality Control for the first 10,000 brain imaging datasets from UK Biobank. Neuroimage, 166, 400-424. doi:10.1016/j.neuroimage.2017.10.034

Boisvert, M. M., Erikson, G. A., Shokhirev, M. N., \& Allen, N. J. (2018). The Aging Astrocyte Transcriptome from Multiple Regions of the Mouse Brain. Cell Rep, 22(1), 269-285. doi:10.1016/j.celrep.2017.12.039

Bycroft, C., Freeman, C., Petkova, D., Band, G., Elliott, L. T., Sharp, K., . . Marchini, J. (2018). The UK Biobank resource with deep phenotyping and genomic data. Nature, 562(7726), 203-209. doi:10.1038/s41586-018-0579-Z

Carlesimo, G. A., Piras, F., Orfei, M. D., Iorio, M., Caltagirone, C., \& Spalletta, G. (2015). Atrophy of presubiculum and subiculum is the earliest hippocampal anatomical marker of Alzheimer's disease. Alzheimer's \& dementia (Amsterdam, Netherlands), 1(1), 24-32. doi:10.1016/j.dadm.2014.12.001

Chaudhury, S., Brookes, K. J., Patel, T., Fallows, A., Guetta-Baranes, T., Turton, J. C., . . . Thomas, A. J. (2019). Alzheimer's disease polygenic risk score as a predictor of conversion from mild-cognitive impairment. Translational Psychiatry, 9(1), 154. doi:10.1038/s41398-019-0485-7

Choi, S. W., Mak, T. S.-H., \& O'Reilly, P. F. (2020). Tutorial: a guide to performing polygenic risk score analyses. Nature Protocols. doi:10.1038/s41596-020-0353-1 
medRxiv preprint doi: https://doi.org/10.1101/2020.10.24.20218925; this version posted October 27,2020 . The copyright holder for this preprint (which was not certified by peer review) is the author/funder, who has granted medRxiv a license to display the preprint in All rights reserved. No reuse allowed without permission.

Daugherty, A. M., Bender, A. R., Raz, N., \& Ofen, N. (2016). Age differences in hippocampal subfield volumes from childhood to late adulthood. Hippocampus, 26(2), 220-228. doi:10.1002/hipo.22517

de Flores, R., La Joie, R., \& Chetelat, G. (2015). Structural imaging of hippocampal subfields in healthy aging and Alzheimer's disease. Neuroscience, 309, 29-50. doi:10.1016/j.neuroscience.2015.08.033

Desikan, R. S., Schork, A. J., Wang, Y., Thompson, W. K., Dehghan, A., Ridker, P. M., ... Dale, A. M. (2015). Polygenic Overlap Between C-Reactive Protein, Plasma Lipids, and Alzheimer Disease. Circulation, 131(23), 2061-2069. doi:10.1161/circulationaha.115.015489

Dezhina, Z., Ranlund, S., Kyriakopoulos, M., Williams, S. C. R., \& Dima, D. (2018). A systematic review of associations between functional MRI activity and polygenic risk for schizophrenia and bipolar disorder. Brain Imaging Behav. doi:10.1007/s11682-018-9879-z

Duarte-Guterman, P., Yagi, S., Chow, C., \& Galea, L. A. (2015). Hippocampal learning, memory, and neurogenesis: Effects of sex and estrogens across the lifespan in adults. Horm Behav, 74, 37-52. doi:10.1016/j.yhbeh.2015.05.024

Elliott, L. T., Sharp, K., Alfaro-Almagro, F., Shi, S., Miller, K. L., Douaud, G., . . Smith, S. M. (2018). Genome-wide association studies of brain imaging phenotypes in UK Biobank. Nature, 562(7726), 210-216. doi:10.1038/s41586-018-0571-7

Elman, J. A., Panizzon, M. S., Gillespie, N. A., Hagler Jr, D. J., Fennema-Notestine, C., Eyler, L. T., ... Kremen, W. S. (2019). Genetic architecture of hippocampal subfields on standard resolution MRI: How the parts relate to the whole. Human Brain Mapping, 40(5), 15281540. doi:10.1002/hbm.24464 
medRxiv preprint doi: https://doi.org/10.1101/2020.10.24.20218925; this version posted October 27,2020 . The copyright holder for this preprint (which was not certified by peer review) is the author/funder, who has granted medRxiv a license to display the preprint in All rights reserved. No reuse allowed without permission.

Escott-Price, V., Sims, R., Bannister, C., Harold, D., Vronskaya, M., Majounie, E., .. . Williams, J. (2015). Common polygenic variation enhances risk prediction for Alzheimer's disease. Brain, 138(Pt 12), 3673-3684. doi:10.1093/brain/awv268

Euesden, J., Lewis, C. M., \& O'Reilly, P. F. (2015). PRSice: Polygenic Risk Score software. Bioinformatics, 31(9), 1466-1468. doi:10.1093/bioinformatics/btu848

Farrer, L. A., Cupples, L. A., Haines, J. L., Hyman, B., Kukull, W. A., Mayeux, R., . . van Duijn, C. M. (1997). Effects of age, sex, and ethnicity on the association between apolipoprotein E genotype and Alzheimer disease. A meta-analysis. APOE and Alzheimer Disease Meta Analysis Consortium. Jama, 278(16), 1349-1356. Retrieved from https://jamanetwork.com/journals/jama/articlepdf/418446/jama 278 16 041.pdf

Fernandez, C. G., Hamby, M. E., McReynolds, M. L., \& Ray, W. J. (2019). The Role of APOE4 in Disrupting the Homeostatic Functions of Astrocytes and Microglia in Aging and Alzheimer's Disease. Frontiers in Aging Neuroscience, 11(14). doi:10.3389/fnagi.2019.00014

Fischl, B., \& Dale, A. M. (2000). Measuring the thickness of the human cerebral cortex from magnetic resonance images. Proc Natl Acad Sci U S A, 97(20), 11050-11055. doi:10.1073/pnas.200033797

Foley, S. F., Tansey, K. E., Caseras, X., Lancaster, T., Bracht, T., Parker, G., . . . Linden, D. E. (2017). Multimodal Brain Imaging Reveals Structural Differences in Alzheimer's Disease Polygenic Risk Carriers: A Study in Healthy Young Adults. Biol Psychiatry, 81(2), $154-$ 161. doi:10.1016/j.biopsych.2016.02.033

Hof, P. R., Glannakopoulos, P., \& Bouras, C. (1996). The neuropathological changes associated with normal brain aging. Histol Histopathol, 11(4), 1075-1088. 
medRxiv preprint doi: https://doi.org/10.1101/2020.10.24.20218925; this version posted October 27, 2020. The copyright holder for this preprint (which was not certified by peer review) is the author/funder, who has granted medRxiv a license to display the preprint in All rights reserved. No reuse allowed without permission.

Hollands, C., Bartolotti, N., \& Lazarov, O. (2016). Alzheimer's Disease and Hippocampal Adult Neurogenesis; Exploring Shared Mechanisms. Front Neurosci, 10, 178. doi:10.3389/fnins.2016.00178

Iglesias, J. E., Augustinack, J. C., Nguyen, K., Player, C. M., Player, A., Wright, M., .. . Van Leemput, K. (2015). A computational atlas of the hippocampal formation using ex vivo, ultra-high resolution MRI: Application to adaptive segmentation of in vivo MRI. Neuroimage, 115, 117-137. doi:10.1016/j.neuroimage.2015.04.042

Kang, D. W., Lim, H. K., Joo, S.-H., Lee, N. R., \& Lee, C. U. (2018). The association between hippocampal subfield volumes and education in cognitively normal older adults and amnestic mild cognitive impairment patients. Neuropsychiatric disease and treatment, 14, 143-152. doi:10.2147/NDT.S151659

Kerchner, G. A., Berdnik, D., Shen, J. C., Bernstein, J. D., Fenesy, M. C., Deutsch, G. K., . . Rutt, B. K. (2014). APOE epsilon4 worsens hippocampal CA1 apical neuropil atrophy and episodic memory. Neurology, 82(8), 691-697. doi:10.1212/wnl.0000000000000154

Koss, W. A., \& Frick, K. M. (2017). Sex differences in hippocampal function. J Neurosci Res, 95(1-2), 539-562. doi:10.1002/jnr.23864

Lambert, J. C., Ibrahim-Verbaas, C. A., Harold, D., Naj, A. C., Sims, R., Bellenguez, C., .. . Amouyel, P. (2013). Meta-analysis of 74,046 individuals identifies 11 new susceptibility loci for Alzheimer's disease. Nature Genetics, 45(12), 1452-1458. doi:10.1038/ng.2802

Leonenko, G., Sims, R., Shoai, M., Frizzati, A., Bossù, P., Spalletta, G., . . Escott-Price, V. (2019). Polygenic risk and hazard scores for Alzheimer's disease prediction. Annals of Clinical and Translational Neurology, 6(3), 456-465. doi:10.1002/acn3.716

Li, B., Shi, J., Gutman, B. A., Baxter, L. C., Thompson, P. M., Caselli, R. J., . . Alzheimer's Disease Neuroimaging, I. (2016). Influence of APOE Genotype on Hippocampal Atrophy 
medRxiv preprint doi: https://doi.org/10.1101/2020.10.24.20218925; this version posted October 27, 2020. The copyright holder for this preprint (which was not certified by peer review) is the author/funder, who has granted medRxiv a license to display the preprint in All rights reserved. No reuse allowed without permission.

over Time - An N=1925 Surface-Based ADNI Study. PLoS One, 11(4), e0152901. doi:10.1371/journal.pone.0152901

Li, J., Zhang, X., Li, A., Liu, S., Qin, W., Yu, C., . . Jiang, T. (2018). Polygenic risk for Alzheimer's disease influences precuneal volume in two independent general populations. Neurobiol Aging, 64, 116-122. doi:10.1016/j.neurobiolaging.2017.12.022

Malykhin, N. V., Huang, Y., Hrybouski, S., \& Olsen, F. (2017). Differential vulnerability of hippocampal subfields and anteroposterior hippocampal subregions in healthy cognitive aging. Neurobiol Aging, 59, 121-134. doi:10.1016/j.neurobiolaging.2017.08.001

McCaw, Z. R., Lane, J. M., Saxena, R., Redline, S., \& Lin, X. (2019). Operating characteristics of the rank-based inverse normal transformation for quantitative trait analysis in genomewide association studies. Biometrics, $n / a(\mathrm{n} / \mathrm{a})$. doi:10.1111/biom.13214

McEwen, B. S. (2010). Stress, sex, and neural adaptation to a changing environment: mechanisms of neuronal remodeling. Ann N Y Acad Sci, 1204(s1), 38-59. doi:10.1111/j.1749$6632.2010 .05568 . x$

Miller, K. L., Alfaro-Almagro, F., Bangerter, N. K., Thomas, D. L., Yacoub, E., Xu, J., .. . Smith, S. M. (2016). Multimodal population brain imaging in the UK Biobank prospective epidemiological study. Nature Neuroscience, 19(11), 1523-1536. doi:10.1038/nn.4393

Mueller, S. G., Schuff, N., Yaffe, K., Madison, C., Miller, B., \& Weiner, M. W. (2010).

Hippocampal atrophy patterns in mild cognitive impairment and Alzheimer's disease.

Human Brain Mapping, 31(9), 1339-1347. doi:10.1002/hbm.20934

Mueller, S. G., Stables, L., Du, A. T., Schuff, N., Truran, D., Cashdollar, N., \& Weiner, M. W. (2007). Measurement of hippocampal subfields and age-related changes with high resolution MRI at 4T. Neurobiol Aging, 28(5), 719-726.

doi:10.1016/j.neurobiolaging.2006.03.007 
medRxiv preprint doi: https://doi.org/10.1101/2020.10.24.20218925; this version posted October 27, 2020. The copyright holder for this preprint (which was not certified by peer review) is the author/funder, who has granted medRxiv a license to display the preprint in All rights reserved. No reuse allowed without permission.

Nobis, L., Manohar, S. G., Smith, S. M., Alfaro-Almagro, F., Jenkinson, M., Mackay, C. E., \& Husain, M. (2019). Hippocampal volume across age: Nomograms derived from over 19,700 people in UK Biobank. NeuroImage. Clinical, 23, 101904-101904. doi:10.1016/j.nicl.2019.101904

Padurariu, M., Ciobica, A., Mavroudis, I., Fotiou, D., \& Baloyannis, S. (2012). Hippocampal neuronal loss in the CA1 and CA3 areas of Alzheimer's disease patients. Psychiatr Danub, 24(2), 152-158.

Perl, D. P. (2010). Neuropathology of Alzheimer's disease. The Mount Sinai journal of medicine, New York, 77(1), 32-42. doi:10.1002/msj.20157

Pini, L., Pievani, M., Bocchetta, M., Altomare, D., Bosco, P., Cavedo, E., . . Frisoni, G. B. (2016). Brain atrophy in Alzheimer's Disease and aging. Ageing Res Rev, 30, 25-48. doi:10.1016/j.arr.2016.01.002

Quattrini, G., Pievani, M., Jovicich, J., Aiello, M., Bargalló, N., Barkhof, F., . . Marizzoni, M. (2020). Amygdalar nuclei and hippocampal subfields on MRI: Test-retest reliability of automated volumetry across different MRI sites and vendors. NeuroImage, 218, 116932. doi:https://doi.org/10.1016/j.neuroimage.2020.116932

Scharfman, H. E., \& MacLusky, N. J. (2017). Sex differences in hippocampal area CA3 pyramidal cells. J Neurosci Res, 95(1-2), 563-575. doi:10.1002/jnr.23927

Shing, Y. L., Rodrigue, K. M., Kennedy, K. M., Fandakova, Y., Bodammer, N., Werkle-Bergner, M., . . Raz, N. (2011). Hippocampal subfield volumes: age, vascular risk, and correlation with associative memory. Front Aging Neurosci, 3, 2. doi:10.3389/fnagi.2011.00002

Sudlow, C., Gallacher, J., Allen, N., Beral, V., Burton, P., Danesh, J., . . Collins, R. (2015). UK biobank: an open access resource for identifying the causes of a wide range of complex diseases of middle and old age. PLoS Med, 12(3), e1001779. doi:10.1371/journal.pmed.1001779 
medRxiv preprint doi: https://doi.org/10.1101/2020.10.24.20218925; this version posted October 27,2020 . The copyright holder for this preprint (which was not certified by peer review) is the author/funder, who has granted medRxiv a license to display the preprint in All rights reserved. No reuse allowed without permission.

Tingley, D., Yamamoto, T., Hirose, K., Keele, L., Imai, K. (2014). Mediation: R package for causal mediation analysis. Journal of Statistical Software, 59(5), 1-38.

van der Meer, D., Rokicki, J., Kaufmann, T., Cordova-Palomera, A., Moberget, T., Alnaes, D., ... Westlye, L. T. (2018). Brain scans from 21,297 individuals reveal the genetic architecture of hippocampal subfield volumes. Mol Psychiatry. doi:10.1038/s41380-018-0262-7

van Eijk, L., Hansell, N. K., Strike, L. T., Couvy-Duchesne, B., de Zubicaray, G. I., Thompson, P. M., ... Wright, M. J. (2020). Region-specific sex differences in the hippocampus. NeuroImage, 215, 116781. doi:https://doi.org/10.1016/j.neuroimage.2020.116781

Wisse, L. E., Biessels, G. J., Heringa, S. M., Kuijf, H. J., Koek, D. H., Luijten, P. R., \& Geerlings, M. I. (2014). Hippocampal subfield volumes at 7T in early Alzheimer's disease and normal aging. Neurobiol Aging, 35(9), 2039-2045. doi:10.1016/j.neurobiolaging.2014.02.021

Worker, A., Dima, D., Combes, A., Crum, W. R., Streffer, J., Einstein, S., . . O'Daly, O. (2018). Test-retest reliability and longitudinal analysis of automated hippocampal subregion volumes in healthy ageing and Alzheimer's disease populations. Human Brain Mapping, 39(4), 1743-1754. doi:10.1002/hbm.23948

Xiao, E., Chen, Q., Goldman, A. L., Tan, H. Y., Healy, K., Zoltick, B., . . Mattay, V. S. (2017). Late-Onset Alzheimer's Disease Polygenic Risk Profile Score Predicts Hippocampal Function. Biol Psychiatry Cogn Neurosci Neuroimaging, 2(8), 673-679. doi:10.1016/j.bpsc.2017.08.004

Zhao, W., Wang, X., Yin, C., He, M., Li, S., \& Han, Y. (2019). Trajectories of the Hippocampal Subfields Atrophy in the Alzheimer's Disease: A Structural Imaging Study. Frontiers in Neuroinformatics, 13, 13. Retrieved from https://www.frontiersin.org/article/10.3389/fninf.2019.00013 
medRxiv preprint doi: https://doi.org/10.1101/2020.10.24.20218925; this version posted October 27, 2020. The copyright holder for this preprint (which was not certified by peer review) is the author/funder, who has granted medRxiv a license to display the preprint in All rights reserved. No reuse allowed without permission.

Zheng, F., Cui, D., Zhang, L., Zhang, S., Zhao, Y., Liu, X., . . Qiu, J. (2018). The Volume of Hippocampal Subfields in Relation to Decline of Memory Recall Across the Adult Lifespan. Front Aging Neurosci, 10, 320. doi:10.3389/fnagi.2018.00320

Table 1. UK biobank sample characteristics and mean (standard deviation) of hippocampal subfield volumes in $\mathrm{mm}^{3}$

\section{UK Biobank sample characteristics}

\begin{tabular}{|c|c|c|c|c|}
\hline Sample size & \multicolumn{4}{|c|}{17,161} \\
\hline Age (mean, SD) & \multicolumn{4}{|c|}{$62.39(7.43)$ years } \\
\hline Gender (n, \%) & \multicolumn{4}{|c|}{$9256(53.9 \%)$ females; 7905 (46.1\%) males } \\
\hline Hippocampal subfields & Left hemisphere & Right hemisphere & $t$ & $p$ \\
\hline CA1 & $637.09(75.61)$ & $666.69(79.81)$ & -0.095 & 0.924 \\
\hline CA2-3 & $214.18(30.23)$ & $237.29(32.43)$ & -0.239 & 0.812 \\
\hline CA4 & $260.59(29.34)$ & $276.30(31.72)$ & 0.164 & 0.870 \\
\hline Subiculum & $436.56(50.21)$ & $438.32(49.54)$ & 0.140 & 0.893 \\
\hline Presubiculum & $307.85(38.70)$ & $297.23(36.42)$ & -0.061 & 0.951 \\
\hline Parasubiculum & $64.97(13.14)$ & $62.89(12.17)$ & -0.072 & 0.943 \\
\hline Hippocampal tail & $519.89(70.64)$ & $560.88(72.71)$ & -0.025 & 0.980 \\
\hline Hippocampal fissure & $170.80(31.39)$ & $176.18(32.44)$ & 0.277 & 0.781 \\
\hline HATA & $61.29(9.78)$ & $66.00(9.97)$ & 0.212 & 0.832 \\
\hline Molecular layer & $573.55(62.41)$ & $592.21(64.70)$ & 0.012 & 0.990 \\
\hline GC-DG & $302.41(34.23)$ & $318.72(36.45)$ & 0.093 & 0.926 \\
\hline Fimbria & $79.06(18.60)$ & $73.11(17.11)$ & -0.659 & 0.510 \\
\hline Whole hippocampus & $3457.44(351.80)$ & $3589.66(365.72)$ & -0.041 & 0.967 \\
\hline
\end{tabular}


medRxiv preprint doi: https://doi.org/10.1101/2020.10.24.20218925; this version posted October 27, 2020. The copyright holder for this preprint (which was not certified by peer review) is the author/funder, who has granted medRxiv a license to display the preprint in All rights reserved. No reuse allowed without permission.

Abbreviations: CA, cornu ammonis; HATA, hippocampus-amygdala-transition-area;

GC-DG, granule cell layer of dentate gyrus. Significant differences were assessed

between left and right hippocampal sub-fields using t-tests.

Table 2. Associations between hippocampal subfield volumes and $\mathrm{PRS}_{\mathrm{AD}}$ (threshold $5 \times 10^{-8}$ )

\begin{tabular}{|c|c|c|c|c|c|}
\hline Hippocampal subfields & $\beta$ & SE & $t$ & $p$ & Adjusted p-value \\
\hline Left CA1 & -0.0209 & 0.0061 & -3.4196 & 0.000629 & $0.005448^{*}$ \\
\hline Right CA1 & -0.0112 & 0.0062 & -1.8230 & 0.068324 & 0.118428 \\
\hline Left CA2-3 & -0.0130 & 0.0067 & -1.9260 & 0.054116 & 0.100501 \\
\hline Right CA2-3 & -0.0087 & 0.0065 & -1.3361 & 0.181525 & 0.262203 \\
\hline Left CA4 & -0.0160 & 0.0063 & -2.5402 & 0.011088 & $0.028828^{*}$ \\
\hline Right CA4 & -0.0098 & 0.0062 & -1.5664 & 0.117263 & 0.179343 \\
\hline Left fimbria & 0.0063 & 0.0069 & 0.9130 & 0.361248 & 0.494339 \\
\hline Right fimbria & 0.0015 & 0.0069 & 0.2107 & 0.833092 & 0.902516 \\
\hline Left GC-DG & -0.0180 & 0.0061 & -2.9459 & 0.003225 & $0.011978 *$ \\
\hline Right GC-DG & -0.0108 & 0.0061 & -1.7604 & 0.078356 & 0.127328 \\
\hline Left HATA & -0.0254 & 0.0068 & -3.7449 & 0.000181 & $0.003688^{*}$ \\
\hline Right HATA & -0.0213 & 0.0067 & -3.1799 & 0.001476 & $0.009595 *$ \\
\hline Left hippocampal fissure & -0.0046 & 0.0069 & -0.6652 & 0.505960 & 0.657749 \\
\hline Right hippocampal fissure & 0.0003 & 0.0067 & 0.0496 & 0.960448 & 0.960448 \\
\hline Left hippocampal tail & -0.0203 & 0.0070 & -2.8890 & 0.003869 & $0.012574 *$ \\
\hline Right hippocampal tail & -0.0250 & 0.0069 & -3.6305 & 0.000284 & $0.003688^{*}$ \\
\hline Left molecular layer & -0.0179 & 0.0059 & -3.0264 & 0.002479 & $0.010742 *$ \\
\hline Right molecular layer & -0.0120 & 0.0059 & -2.0313 & 0.042240 & 0.084480 \\
\hline Left parasubiculum & -0.0027 & 0.0070 & -0.3859 & 0.699589 & 0.826787 \\
\hline Right parasubiculum & -0.0036 & 0.0063 & -0.5740 & 0.565988 & 0.700747 \\
\hline Left presubiculum & -0.0017 & 0.0064 & -0.2625 & 0.792912 & 0.896335 \\
\hline Right presubiculum & 0.0004 & 0.0070 & 0.0592 & 0.952767 & 0.960448 \\
\hline Left subiculum & -0.0128 & 0.0062 & -2.0469 & 0.040680 & 0.084481 \\
\hline Right subiculum & -0.0156 & 0.0063 & -2.4834 & 0.013024 & $0.030785^{*}$ \\
\hline
\end{tabular}


medRxiv preprint doi: https://doi.org/10.1101/2020.10.24.20218925; this version posted October 27, 2020. The copyright holder for this preprint (which was not certified by peer review) is the author/funder, who has granted medRxiv a license to display the preprint in All rights reserved. No reuse allowed without permission.

$\begin{array}{llllll}\text { Left whole hippocampus } & -0.0180 & 0.0058 & -3.1134 & 0.001853 & 0.009633^{*} \\ \text { Right whole hippocampus } & -0.0150 & 0.0058 & -2.5944 & 0.009482 & 0.027393^{*}\end{array}$

Abbreviations: HATA, hippocampus-amygdala-transition-area; CA1, cornu ammonis; GC-DG, granule cell layer of dentate gyrus. *Denotes statistically significant results after FDR correction. Note: This analysis was run with the full regression model (adjusted for age, age2, sex, age $\times$ sex (i.e. age and sex interaction), age $2 \times$ sex (i.e. age 2 and sex interaction), intracranial volume (ICV), head position in the scanner, and ten genetic principal components). The full results can be found in Supplementary table 1. 
medRxiv preprint doi: https://doi.org/10.1101/2020.10.24.20218925; this version posted October 27, 2020. The copyright holder for this preprint (which was not certified by peer review) is the author/funder, who has granted medRxiv a license to display the preprint in All rights reserved. No reuse allowed without permission.

Figure 1. Forest plot with bilateral HATA, left CA1, and right hippocampal tail for all the group comparisons between Q1, first quartile, and Q4, last quartile.

Note: The subgroups include overall, young, old, female, male, female-young, female-old, maleyoung, and male-old.

Supplementary table 1 . Results from base regression model examining $\mathrm{PRS}_{\mathrm{AD}}$ and hippocampal subfield volumes while controlling for age, age ${ }^{2}$, sex, age $\times$ sex, age ${ }^{2} \times$ sex, intracranial volume (ICV), head position in the scanner, and ten genetic principal components.

Abbreviations: SE, standard error; CA, cornu ammonis; DG, granule cell layer of dentate gyrus; HATA, hippocampal-amygdala-transition-area

Supplementary table 2. Results from base regression model examining $\mathrm{PRS}_{\mathrm{AD}}$ and hippocampal subfield volumes while controlling for covariates including total hippocampal volume Abbreviations: SE, standard error; CA, cornu ammonis; DG, granule cell layer of dentate gyrus; HATA, hippocampal-amygdala-transition-area

Supplementary table 3. Results from base regression model examining PRSAD and hippocampal head, body, and tail volumes segmented using FreeSurfer 7.1.0

Abbreviations: SE, standard error; CA, cornu ammonis; DG, granule cell layer of dentate gyrus; HATA, hippocampal-amygdala-transition-area

Supplementary table 4. Regression model of $\mathrm{PRS}_{\mathrm{AD}}$ without $A p o E$ locus and hippocampal subfield volumes while controlling for age, $\operatorname{age}^{2}$, sex, age $\times$ sex, $\operatorname{age}^{2} \times$ sex, intracranial volume (ICV), head position in the scanner, and ten genetic principal components. 
medRxiv preprint doi: https://doi.org/10.1101/2020.10.24.20218925; this version posted October 27,2020 . The copyright holder for this preprint (which was not certified by peer review) is the author/funder, who has granted medRxiv a license to display the preprint in All rights reserved. No reuse allowed without permission.

Abbreviations: SE, standard error; CA, cornu ammonis; DG, granule cell layer of dentate gyrus; HATA, hippocampal-amygdala-transition-area

Supplementary table 5. Influence of low and high $\mathrm{PRS}_{\mathrm{AD}}$ on hippocampal subfield volumes Abbreviations: OR, odds ratio; Q1, first quartile; Q2, second quartile; Q3, third quartile; SE, standard error; CA, cornu ammonis; DG, granule cell layer of dentate gyrus; HATA, hippocampal-amygdala-transition-area

Supplementary table 6. Risk for hippocampal subfield volume loss between low and high PRS $\mathrm{AD}_{\mathrm{D}}$ in younger participants $(\leq 63$ years old $)$

Abbreviations: OR, odds ratio; Q1, first quartile; Q2, second quartile; Q3, third quartile; Q4all, comparison between fourth quartile and the rest of the quartiles; SE, standard error; CA, cornu ammonis; GC-DG, granule cell layer of dentate gyrus; HATA, hippocampal-amygdala-transitionarea

Note: Refer to ORQ1 and pval_prsQ1_adj for hippocampal volumes between low and high $\mathrm{PRS}_{\mathrm{AD}}$

Supplementary Table 7. Risk for hippocampal subfield volume loss between low and high PRS $\mathrm{AD}_{\mathrm{A}}$ in older participants $(>63$ years old)

Abbreviations: OR, odds ratio; Q1, first quartile; Q2, second quartile; Q3, third quartile; Q4all, comparison between fourth quartile and the rest of the quartiles; SE, standard error; CA, cornu ammonis; GC-DG, granule cell layer of dentate gyrus; HATA, hippocampal-amygdala-transitionarea

Note: Refer to ORQ1 and pval_prsQ1_adj for hippocampal volumes between low and high $\mathrm{PRS}_{\mathrm{AD}}$. 
medRxiv preprint doi: https://doi.org/10.1101/2020.10.24.20218925; this version posted October 27,2020 . The copyright holder for this preprint (which was not certified by peer review) is the author/funder, who has granted medRxiv a license to display the preprint in All rights reserved. No reuse allowed without permission.

Supplementary table 8. Hippocampal subfield volumes associations with $\mathrm{PRS}_{\mathrm{AD}}$ split into quartiles for females

Abbreviations: OR, odds ratio; Q1, first quartile; Q2, second quartile; Q3, third quartile; Q4all, comparison between fourth quartile and the rest of the quartiles; SE, standard error; CA, cornu ammonis; GC-DG, granule cell layer of dentate gyrus; HATA, hippocampal-amygdala-transitionarea

Note: Refer to ORQ1 and pval_prsQ1_adj for hippocampal volumes between low and high $\mathrm{PRS}_{\mathrm{AD}}$.

Supplementary table 9. Hippocampal subfield volumes associations with $\mathrm{PRS}_{\mathrm{AD}}$ split into quartiles for males

Abbreviations: OR, odds ratio; Q1, first quartile; Q2, second quartile; Q3, third quartile; Q4all, comparison between fourth quartile and the rest of the quartiles; SE, standard error; CA, cornu ammonis; GC-DG, granule cell layer of dentate gyrus; HATA, hippocampal-amygdala-transitionarea

Note: Refer to ORQ1 and pval_prsQ1_adj for hippocampal volumes between low and high $\mathrm{PRS}_{\mathrm{AD}}$

Supplementary tables 10-13. Hippocampal subfield volumes associations with $\mathrm{PRS}_{\mathrm{AD}}$ split into quartiles for age and sex i.e. females $\leq 63$ years (Supplementary table 10), females $>63$ years (Supplementary table 11), males $\leq 63$ years (Supplementary table 12), males $>63$ years (Supplementary table 13$)$.

Abbreviations: OR, odds ratio; Q1, first quartile; Q2, second quartile; Q3, third quartile; Q4all, comparison between fourth quartile and the rest of the quartiles. SE, standard error; CA, cornu 
medRxiv preprint doi: https://doi.org/10.1101/2020.10.24.20218925; this version posted October 27,2020 . The copyright holder for this preprint (which was not certified by peer review) is the author/funder, who has granted medRxiv a license to display the preprint in All rights reserved. No reuse allowed without permission.

ammonis; GC-DG, granule cell layer of dentate gyrus; HATA, hippocampal-amygdala-transitionarea

Note: Refer to ORQ1 and pval_prsQ1_adj for hippocampal volumes between low and high $\mathrm{PRS}_{\mathrm{AD}}$.

Supplementary table 14. Mediation analysis on the effects of age on the relationship between $\mathrm{PRS}_{\mathrm{AD}}$ and hippocampal subfield volumes.

Abbreviations: direct, direct effect of $\mathrm{PRS}_{\mathrm{AD}}$ in in the model with the mediator variable; total, effect of PRS $\mathrm{AD}_{\mathrm{A}}$ in the model without the mediator variable; med, mediation effect (total effect direct effect); CA, cornu ammonis; DG, granule cell layer of dentate gyrus; HATA, hippocampalamygdala-transition-area

Supplementary tables $15-16$. Intersect between hippocampal subfield volumes with bilateral whole hippocampus as covariate (Supplementary Table 15) and bilateral whole hippocampus as independent variable together with other hippocampal subfield volumes (Supplementary Table 16) and PRS $\mathrm{AD}_{\mathrm{A}}$

Note: Highlighted fields are SNPs that reached suggestive significance of $p<0.05$.

Supplementary figure 1. Age and sex trajectory for hippocampal subfield volumes. Quadratic curve was fitted using the residuals adjusted for imaging and principal components. Line represents the fitted curve for age and dots represents the confidence intervals.

Abbreviations: CA, cornu ammonis; DG, granule cell layer of dentate gyrus; HATA, hippocampal-amygdala-transition-area 
medRxiv preprint doi: https://doi.org/10.1101/2020.10.24.20218925; this version posted October 27, 2020. The copyright holder for this preprint (which was not certified by peer review) is the author/funder, who has granted medRxiv a license to display the preprint in All rights reserved. No reuse allowed without permission.

Supplementary figure 2. Forest plot with hippocampal subfields ROI that were not significant for all the group comparisons between Q1, first quartile, and Q4, last quartile.

Note: The subgroups include overall, young, old, female, male, female-young, female-old, maleyoung, and male-old. 


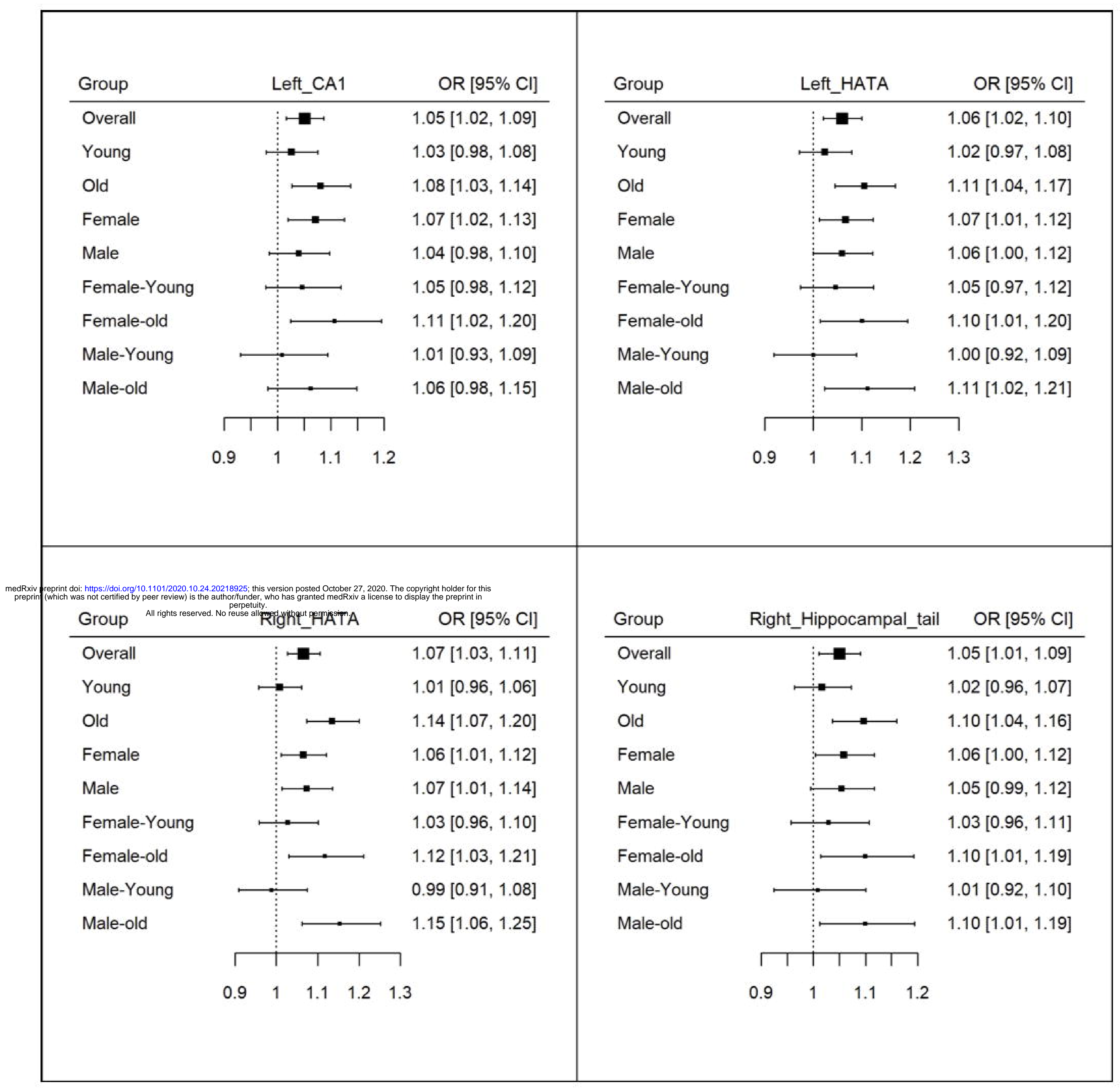

